\title{
Vliv environmentální profilace středních škol na proenvironmentální postoje a jednání studentů
}

\author{
Aleš Bezouška, Jan Činčera \\ Envigogika 2007/II/3 - Recenzované články/ Reviewed Papers \\ Publikováno/Published 30. 12. 2007 \\ DOI: http://dx.doi.org/10.14712/18023061.20
}

\begin{abstract}
Abstrakt:
Článek shrnuje výsledky průzkumu porovnávajícího míru environmentálních postojů a jednání studentů posledních ročníků dvou středních škol profilovaných na environmentální tématiku s kontrolní skupinou.
\end{abstract}

\section{Klíčová slova:}

Environmentální postoje, proenvironmentální jednání, střední školy

\begin{abstract}
:
The article summarizes findings of research on assessing the level of proenvironmental attitudes and behaviour of high school students from environmentally oriented schools. It introduces findings of a small research study focused on the measurement of pro-environmental attitudes and behaviour of students from environmentally oriented secondary schools. The experimental group consisted of 89 students from the fourth year of study from two secondary schools. Both schools in the experimental group declare their orientation towards environmental topics and environmental education is mandatory in their curricula. The control group consisted of 112 final year students from non-environmentally profiled schools. The research showed very small differences in both attitudes and behaviour between the groups and did not support the hypothesis about the higher level of pro-environmental behaviour and attitudes of students attending environmentally oriented schools.
\end{abstract}

\section{Key words:}

Environmental attitudes, environmental behavior, high school 


\section{Úvod}

Problematika environmentální výchovy je u nás v současné době promítnuta jak do již schváleného rámcového vzdělávacího programu pro základní školy, tak do teprve připravovaných rámcových vzdělávacích programů pro školy střední. Implementace př́slušného průřezového programu je dále podporována ze strany nevládních subjektů působících v oblasti environmentální výchovy, jako je zejména Sít středisek ekologické výchovy Pavučina či Klub ekologické výchovy. Oba subjekty podporují vzdělávání učitelů v rámci cyklů kursů pro koordinátory environmentální výchovy, vzdělávání a osvěty.

Environmentální výchova se ale pro školy nemusí stát pouze povinností, ale i určitým marketingovým nástrojem, umožňujícím se škole profilovat tímto směrem a získávat studenty, kteří se o problematiku životního prostředí zajímají. Desítky českých a moravských škol např́klad usilují o získání titulu Ekoškola, který mohou v rámci zapojení do stejnojmenného mezinárodního projektu získat po splnění určitých kritérií v oblasti ekologizace svého provozu a školních kurikulí. Jiné školy vyjadřují svưj zájem o životní prostředí například zavedením speciálních předmětů, zapojením do dalších projektů či úsilím o komplexní proenvironmentální profilaci školy.

Problematickým aspektem tohoto úsilí je neexistence jednotného nástroje pro evaluaci výstupů environmentálního vzdělávání na školách. Přestože monitorování vzdělávacích výstupů může (zejména v kognitivní oblasti) vyvolávat určité pochybnosti, je ž̌ejmé, že bez transparentní evaluace hrozí školám hlásícím se k myšlenkám udržitelného života stagnace a v širším měřítku se myšlenka „ekoškol" může zcela vyprázdnit.

Cílem tohoto výzkumu bylo proto pokusit se vyhodnotit postoje a vzorce jednání studentů posledních ročníků environmentálně orientovaných škol a porovnat je s postoji a jednáním studentů jinak se profilujících středních škol. Základní výzkumná otázka byla: Ovlivňují ekologicky orientované střední školy postoje a jednání svých žáků ve větší míře, než jinak profilované střední školy?

\section{Metodika výzkumu}

\section{Vzorek}

Sběr dat proběhl v květnu a začátkem června roku 2007 v posledních ročnících dvou škol s proenvironmentální profilací - EKO Gymnázium Poděbrady a Střední zemědělská škola a Střední odborná škola Poděbrady, Přírodovědné lyceum. Kontrolní skupinou byli žáci posledního ročníku středních škol Gymnázium Jiřího z Poděbrad a Gymnázium T.G. Masaryka Hustopeče. Celkově byly získány odpovědi od 201 respondentů, z toho 89 studentů z experimentální skupiny (24 chlapců a 65 dívek) a 112 studentů ze skupiny kontrolní (32 chlapců a 80 dívek). Věk studentů se pohyboval od 18 do 21 let.

Obě školy zařazené do experimentální skupiny mají ve svém kurikulu povinný předmět související s environmentální výchovou: Přírodovědné lyceum předmět "Člověk a prostředí" a EKO Gymnázium Poděbrady předmět „Ekologická výchova”. EKO Gymnázium Poděbrady výslovně deklaruje jako svůj cíl profilovat své studenty k trvale udržitelnému životu. Při škole existuje Centrum ekologické výchovy a vzdělávání, které organizuje vzdělávací kursy pro regionální koordinátory EVVO a širší environmentální poradenství. Škola je dále zapojena do projektu Klubu ekologické výchovy „Pilotní střední školy KEV a příprava učitelů pro vzdělávání $k$ udržitelnému rozvoji a ekogramotnosti", jedním z cílů projektu bylo ovlivňovat „postoje k životnímu prostředí a k vývoji společnosti v rámci udržitelného rozvoje" (Glierová, 2007). Studenti školy se zapojují do ekologických olympiád, konferencí, účastní se práce ve studentském parlamentu a třídí ve škole odpady. Žáci Přírodovědného lycea se účastní akcí, 
jako je návštěva záchranné stanice pro handicapovaná zvířata, či ekologická naučná stezka. Také tato škola usiluje o to "formovat jejich pozitivní a odpovědný vztah k prírodě a k životnímu prostředí" (SZEŠ, 2006). Předmět Člověk a prostředí je vyučován od druhého do čtvrtého ročníku studia s celkovou dotací pět hodin týdně.

Školy z kontrolní skupiny se environmentální výchovou zabývají pouze $\mathrm{v}$ rámci souvisejících předmětů (chemie, zeměpis, biologie atd.). Ucelené kurikulum, které by se $\checkmark$ rámci jednoho jediného předmětu zabývalo pouze environmentálními problémy a jejich řešením, na těchto školách chybí. Gymnázium Jiřího z Poděbrad má ve svém školním vzdělávacím plánu environmentální výchovu zařazenou pouze s odkazem na vzdělávací oblasti Člověk a príroda a Člověk a společnost (Gymnázium Jiřího z Poděbrad, 2007). Priority školy leží spíše $v$ oblastech výchovy $k$ občanství a výchovy ke zdraví. Ani Gymnázium T.G.Masaryka v Hustopečích se na oblast environmentální výchovy nijak neorientuje. $V$ přehledu probíhajících projektů dominují historická témata, problematiky udržitelného života se lehce dotýká pouze finanční sbírka na pomoc Súdánu (Gymnázium T.G.Masaryka, 2007).

\section{Dotazník}

Pro potřeby průzkumu byl využit dotazník, poprvé publikovaný v článku Výzkum ekologické gramotnosti studentů středních odborných škol (Činčera, Štěpánek, 2007). Dotazník byl poprvé vyzkoušen při evaluaci tř́letého integrovaného celku P.T. Pozemštán, který v letech 2004-2006 probíhal na Střední odborné pedagogické škole a Gymnáziu Jeronýmova $v$ Liberci. Protože programem prošla část jedné tř́́dy pedagogické školy, byli jako kontrolní skupina využiti studenti z vyššího ročníku v roce 2006 a jako skupina experimentální účastníci projektu $v$ roce 2007. Průzkum prokázal vyšší míru proenvironmentálních postojů u absolventů programu a srovnatelnou míru proenvironmentálního jednání u obou skupin (Činčera, 2007).

V roce 2007 byl nástroj použit pro vyhodnocení předpokládaného rozdílu v postojích a jednáních mezi studenty prvních a posledních ročníku středních odborných škol. Prưzkum neprokázal větší rozdíly $v$ postojích mezi oběma skupinami. Současně naznačil, že sice většina studentů zastává proenvironmentální postoje, jen menšina ale ve svém životě preferuje environmentálně př́iznivé jednání (Činčera, Štěpánek, 2007).

Dotazník se skládá z pěti škál:

1. Revidovaná NEP/DSP škála - otázky 1 až 10.

2. Rozšiřující škála proenvironmentálních postojů - otázky 11 až 16.

3. Škála zvažovaného proenvironmentálního jednání - otázky 17 až 20.

4. Rozšiřující škála proenvironmentálního jednání - otázky 21 až 30.

5. Otevřené otázky.

Vzhledem k tomu, že geneze jednotlivých částí dotazníku byla již popsána (Činčera, Štěpánek, 2007), nebudeme se jí zde již dále věnovat.

\section{Hypotézy}

Cílem výzkumu bylo ověřit následující hypotézy:

H1: Žáci škol, které se profilují na environmentální výchovu, vykazují v posledních ročnících častěji proenvironmentální postoje, jednání a porozumění environmentálním tématům než žáci posledních ročníků jinak profilovaných škol.

H2:Žáci škol, které se profilují na environmentální výchovu, se více angažují při poukazování nebo řešení environmentálních problémů ve svém okolí, popřípadě ve světě, než žáci jinak profilovaných škol. 
Důvody pro formulaci obou hypotéz vyplývaly jak z výzkumné otázky, tak z profilu obou škol zařazených do experimentální skupiny.

\section{Prezentace výsledků}

Na všechny otázky ve škálách 1-4 respondenti odpovídali na bodové stupnici od 1 (nesouhlasím) do 7 (souhlasím). Výsledky zobrazují průměrnou hodnotu odpovědi. Vzhledem k malému počtu chlapců nebyly rozdíly mezi studenty a studentkami vyhodnocovány. Rozdíly mezi skupinami byly dále vyhodnocovány pomocí nepárového T-testu. Respondenti z experimentální skupiny jsou označeni jako „EKO", kontrolní skupina jako "NEKO".

První škála zachycovala míru souhlasu s postoji nového environmentálního paradigmatu $(1,2,6,7,10)$ a dominantního sociálního paradigmatu $(3,4,5,8,9)$ :

1. Budeme-li pokračovat dál stejným směrem, brzy budeme čelit velké ekologické katastrofě.

2. Lidé těžce poškozují životní prostředí.

3. Lidé byli stvořeni, aby vládli zbytku přírody.

4. Lidé mají právo upravovat přírodní prostředí podle svých potřeb.

5. Lidská vynalézavost zajistí, že nikdy neučiníme Zemi neobyvatelnou.

6. Lidské zásahy do př́rody vedou často ke katastrofálním dopadům.

7. Navzdory našim schopnostem jsme stále podřízeni zákonům přírody.

8. Rovnováha v př́rodě je dost silná na to, aby zvládla vliv moderní průmyslové společnosti.

9. Takzvaná ekologická krize, které čelíme, je často přehnaně zveličována.

10. Země je jako kosmická lod's omezeným prostorem a zdroji.

\section{Obrázek 1. Souhlas s postoji NEP}

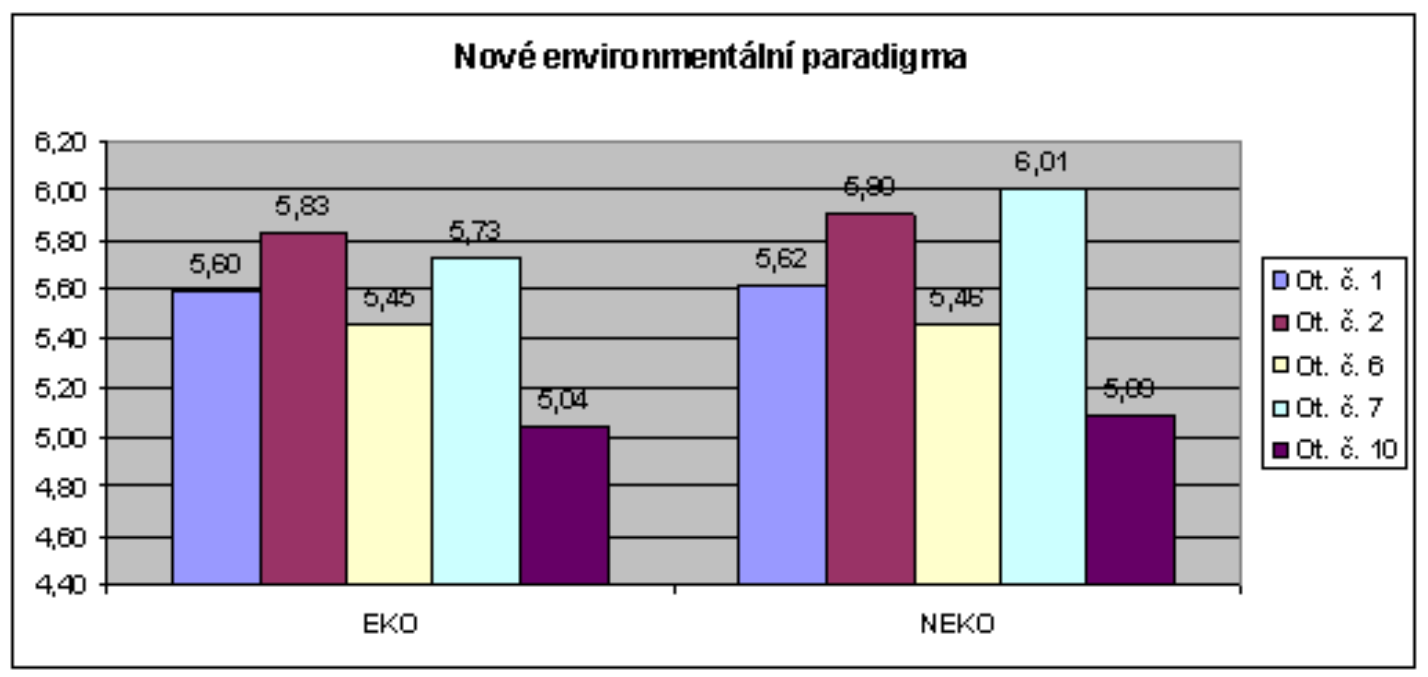


Jak je z grafu patrné, studenti obou skupin škol souhlasí s postoji nového environmentálního paradigmatu. Nepárovým T-testem bylo zjištěno, že naměřené rozdíly nejsou statisticky významné.

\section{Obrázek 2. Souhlas s postoji DSP}

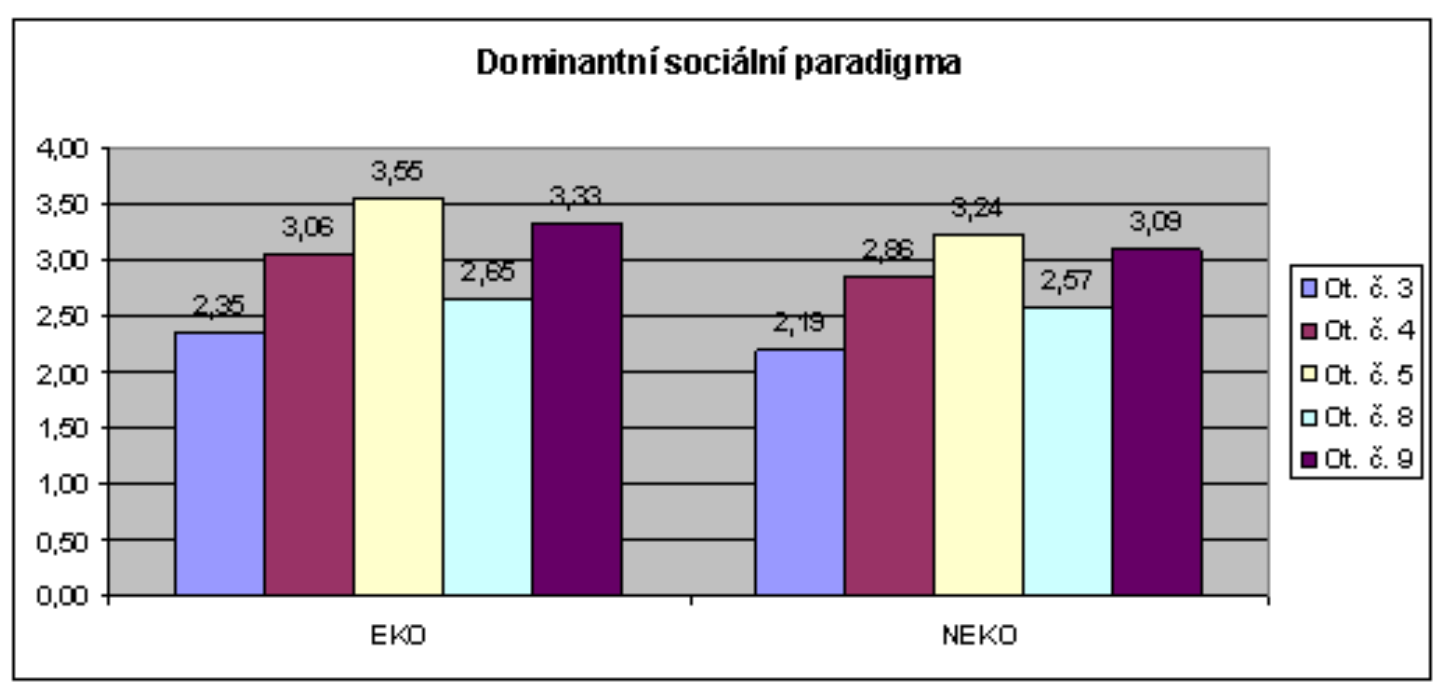

I z druhého grafického znázornění odpovědí studentů je vidět, že souhlas s DSP je u obou skupin relativně stejný, rozdíly nejsou statisticky významné.

Ve druhé škále (11-16) byla dále ověřována míra proenvironmentálnosti postojů studentů. Hodnotící škála byla opět 1 (nesouhlasím) až 7 (souhlasím). Graf zachycuje průměrnou hodnotu jejich odpovědí na tyto otázky.

11. Zvírata a rostliny mají stejná práva existovat, jako lidé.

12. Mám rád/-a místo, ve kterém žiji.

13. Problémy a př́běhy lidí mimo moje vlastní bydliště jsou vzdálené a v podstatě mě nijak neovlivňují.

14. Současná generace má morální závazky vưči budoucím generacím.

15. Přírodní zdroje by měly být využívány spíše pro uspokojení základních životních potřeb než pro materiální blahobyt.

16. Moje jednání nemá žádný faktický vliv na události mimo místo, kde žiji. 


\section{Obrázek 3. Rozšiřující škála proenvironmentálních postojů}

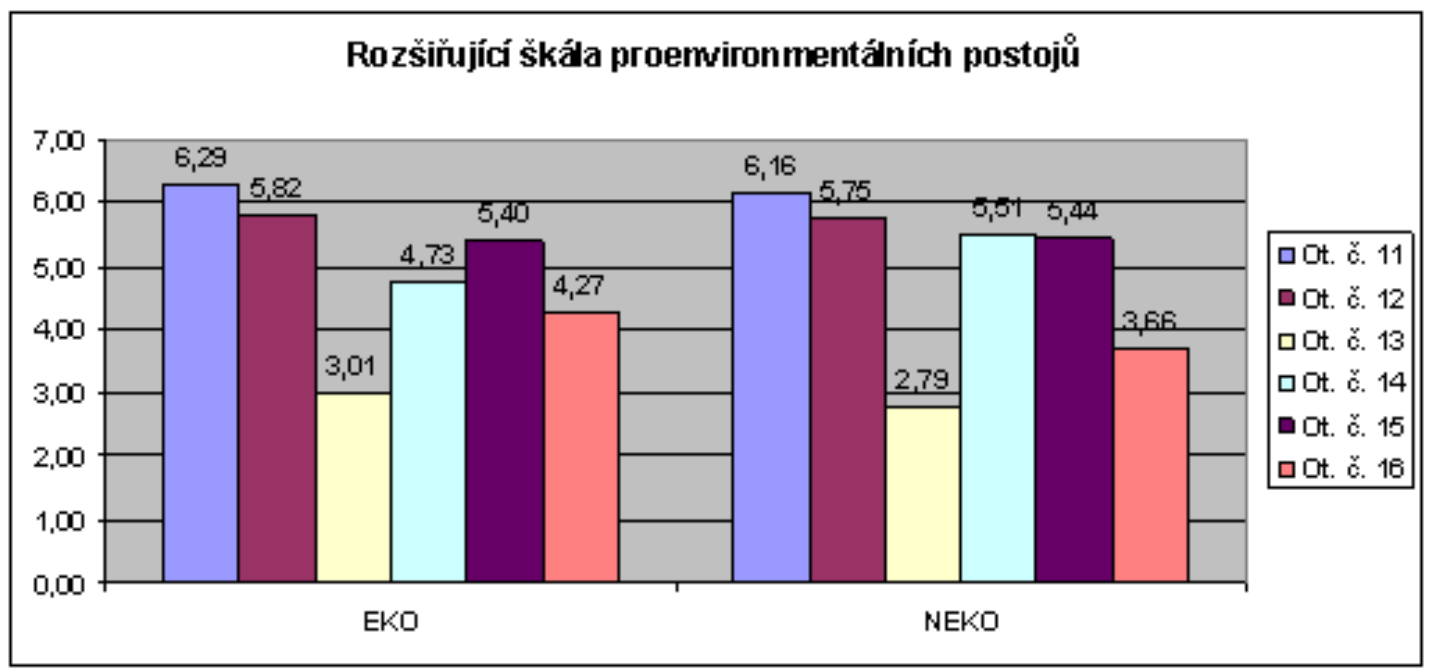

I zde jsou tyto průměry odpovědí celkem vyrovnané pro obě skupiny studentů. Jedinou výjimkou jsou otázky č. 14 a 16, ve kterých se respondenti obou skupin statisticky liší. V obou př́padech vykázali vyšší míru proenvironmentálních postojư respondenti z kontrolní skupiny, tedy ze škol, které se v oblasti environmentální výchovy neprofilují. Jestliže otázku č. 14 můžeme chápat jako esenci principu trvale udržitelného rozvoje, přičemž otázka č. 16 odráží základní porozumění globální provázanosti současného světa a s tím související vědomí odpovědnosti, je tento výsledek zarážející.

Ve třetí škále respondenti vyjadřovali míru své ochoty k proenvironmentálním aktivitám. Bodování probíhalo opět na stupnici od 1 (nesouhlasím) do 7 (souhlasím) na otázky týkající se škály zvažovaného proenvironmentálního jednání. Obr. 4 ukazuje průměrnou hodnotu jejich odpovědí. Čísla otázek odpovídají pořadí v dotazníku.

17. Podepsal/-a bych petici na podporu přísnějších zákonů na ochranu životního prostředí.

18. Účastnil/-a bych se protestní akce proti firmě, která poškozuje životní prostředí.

19. Plánuji zúčastnit se akce organizované ekologickou (environmentální) organizací.

20. Rozšiřoval/-a bych informace vydané environmentální organizací mezi moji rodinu a přátele. 


\section{Obrázek 4. Škála zvažovaného proenvironmentálního jednání}

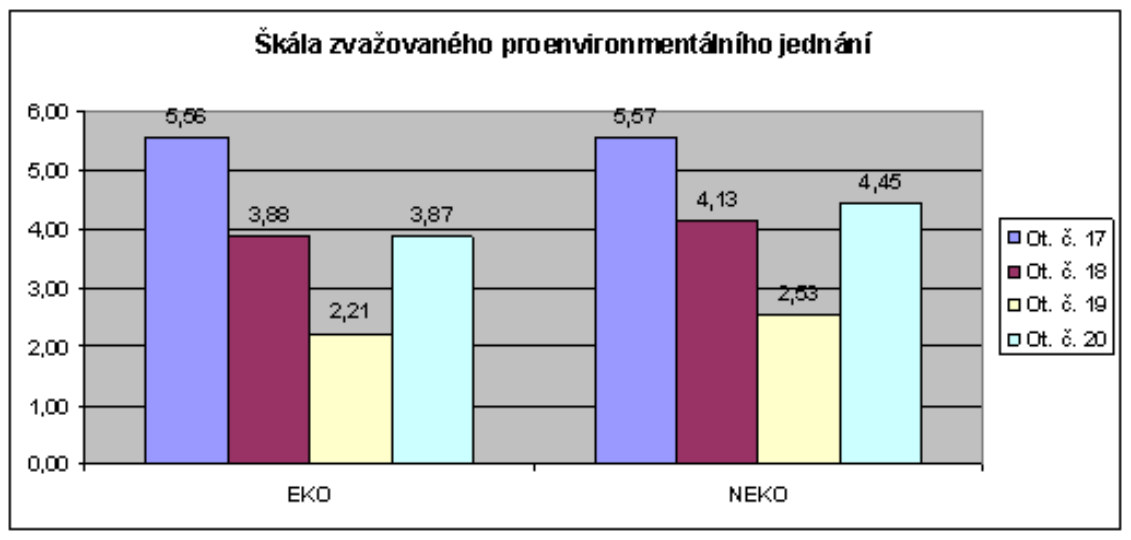

Zatímco rozdíly mezi skupinami nejsou u otázek 17-19 významné, v otázce č. 20 se obě skupiny liší. Vyšší míru ochoty k proenvironmentálnímu jednání přitom opět vykazují respondenti z kontrolní skupiny.

V poslední škále respondenti identifikovali míru, s jakou se zabývají vybranými proenvironmentálními aktivitami. Ke každé aktivitě studenti vybírali ze čtyř možností a ty jsou: "Vícekrát", „Jednou", „Vůbec" a „Nevím". Obr. 5 ukazuje procentuální hodnotu jejich odpovědí na tyto otázky. Čísla otázek odpovídají pořadí v dotazníku.

21. Navštívil/-a přírodu ve svém okolí.

22. Navštívil/-a př́rodu v jiné zemi.

23. Přečetl/-a jakoukoliv publikaci nebo informační zdroj o životním prostředí.

24. Finančně přispěl/-a na ochranu životního prostředí.

25. Finančně přispěl/-a na charitativní účely.

26. Podepsal/-a petici požadující lepší ochranu životního prostředí nebo se jinak písemně vyjádřil pro tento požadavek.

27. Koupil/-a výrobek s ekoznačkou.

28. Koupil/-a si dražší výrobek kvůli tomu, že byl šetrnější k životnímu prostředí.

29. Tř́ídil/-a doma odpad.

30. Využil/-a právo na informace nebo se účastnil/-a jednání s úřady o otázkách souvisejících s životním prostředím. 


\section{Obrázek 5. Rozšiřující škála proenvironmentálního jednání}

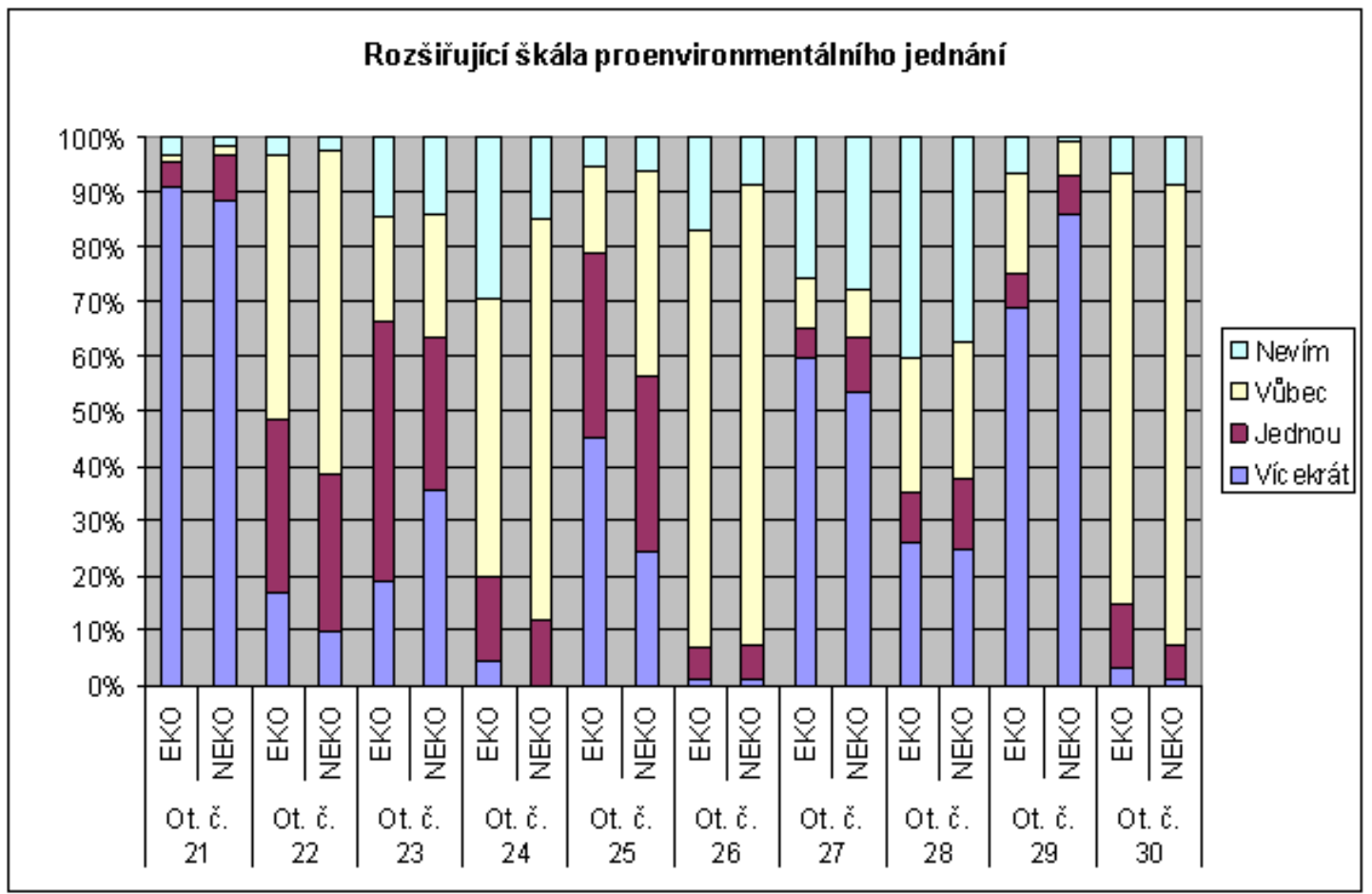

Výpovědi studentů $v$ obou skupinách jsou opět vyrovnané. Statisticky významné jsou rozdíly u otázek č. 25 a 29. Zatímco studenti z kontrolní skupiny častěji přispívají na charitu, studenti z environmentálně orientovaných škol častěji doma tříí odpad.

$\checkmark$ poslední části studenti odpovídali na otevřené otázky. První z nich se týkala porozumění provázanosti jevů ve světě a ostatní dvě se soustředily na výuku environmentální výchovy na středních školách. Pro kategorizaci výsledků byly odpovědi studentů rozděleny do čtyř skupin.

\section{Otevřená otázka č. 1:}

„Představ si, že si chceš koupit nový mobilní telefon. Jakým způsobem takové rozhodnutí ovlivní životní prostředí (pokud má nějaký vliv)? (napiš svůj názor ve 3-5 větách)": 
Obrázek 6. Vliv mobilního telefonu na životní prostředí: procentuální zastoupení jednotlivých kategorií odpovědí

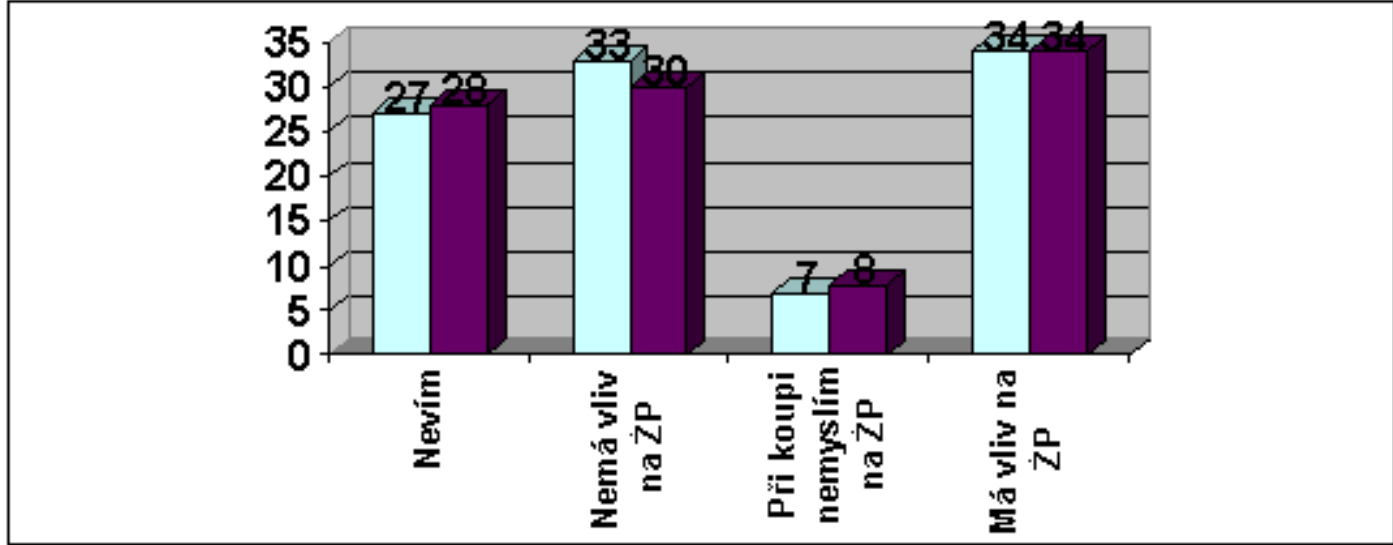

\section{EKO $\square$ NEKO}

$Z$ tabulky je vidět, že obě skupiny téměř z jedné třetiny nevědí, jak mají na danou otázku odpovědět. Další třetina, předpokládá, že koupě mobilního telefonu na životní prostředí vliv nemá. Na druhou stranu je zde třetina studentů, kteří určitou míru vlivu svého spotřebního chování na životní prostředí připustili. Rozdíly mezi experimentální a kontrolní skupinou nejsou významné.

Příklady odpovědí pro každou kategorii:

\section{Studenti s proenvironmentální profilací}

Kategorie: „Nevím"

- „Jo to nevím. Mobilních telefonů je velké množství. Tak, jestli to má nějaký vliv, stejně jako jediná bych nic neovlivnila. Tak si ten mobil koupím!"

- "Netuším."

- „Nemám tušení, jakým způsobem to ovlivní prostředí. Ale já bych si ho nekupovala, protože jeden už mám. A jinej nepotřebuju."

- „Nevím, jestli má mobilní telefon nějaký vliv na životní prostředí. Nikdy jsem o tom nepřemýšlela. Ale asi je dobré nad tím přemýšlet a zamyslet se nad tím."

- „Přiznám se, že netuším."

Kategorie: „Nemá vliv na životní prostředí"

- „Já si myslím, že to nemá vliv."

- „Myslím, že koupě nového mobilního telefonu nijak neovlivňuje životní prostředí, spiše bysme se měli zamýšlet nad koupení nového automobilu, které určitě více znečišt́uje př́rodu než mobil."

- " „ŽP to nijak neovlivní."

- „Koupě nového mobilu životní prostředí neovlivní tak, jako vyhození toho starého." 
- "Na živ. prostředí by to nemělo mít žádný dopad, telefony jsou z umělé hmoty a Ize je určitě recyklovat."

Kategorie: „Při koupi telefonu nemyslím na životní prostředí"

- „Žádnym, telefon si vybírám podle vzhledu a funkce."

- „Myslím si, že mobilní telefon nemá př́liš velký vliv na životní prostředí, proto bych se při výběru nezamýšlela nad životním prostředím."

- "Když si ho budu chtít koupit, tak si ho koupím."

- "Určitě si nebudu vybírat telefon podle vlivu na životní prostředí!"

- „KKdyž si chci koupit nový mobil, v tu chvíli mě tato myšlenka nenapadne."

Kategorie: „Má vliv na životní prostředí"

- "Ovlivní to životní prostředí proto, že se musíme zbavit starého mobilu to zas zatíží ekologii a výroba nového mobilu zase ovlivňuje živ. prostředí."

- „Řekla bych, že továrny na výrobu mob. tel. produkují škodlivé látky. Také ten starý tel. se musí nějak zlikvidovat a určitě materiály, ze kterých je vyroben musí člověk také někde vzít."

- "Vliv to určitě má."

- "Má to vliv. Při koupi telefonu platím DPH. Prodejce bude muset odvést DPH do státního rozpočtu a ty peníze se potom prerozdělí a zbude něco i na zlepšování životního prostředí."

- „Má to vliv. Obsahuje nebezpečné látky, které by měly být bezpečně odstraněny."

\section{Studenti s jinou profilací}

Kategorie: "Nevím"

- "Samozřejmě se budu snažit, aby mé jednání ublí̌ilo přírodě co nejméně. Bohužel ale nevím, jaké důsledky může mít moje jednání."

- „Nevím, jakým způsobem to ovlivní životní prostředí. Nemám přesné informace, do jaké míry jsou mobily škodlivé, ale něco jsem o tom už slyšela."

- "Nevím, jak by to mohlo nějakým způsobem ovlivnit životní prostředí."

- " ???"

- "To opravdu vůbec netuším."

Kategorie: „Nemá vliv na životní prostředí"

- "Životni prostředí takové rozhodnutí poškodí minimálně nebo vůbec."

- „Jakej vliv? 90 \% telefonů je vyráběnejch $v$ Číně, leckdy více značek $v$ jedné továrně. Takže výběrem telefonu nemúžu ovlivnit životní prostředí." 
- „Myslím, že mobilní telefony nemají tak velký vliv na životní prostředí. Ano, musí se kvưli nim stavět vysílače a zásah do prírody zde proběhne, ale nesrovnávala bych to se stavbou dálnice."

- "Mobilní telefon, dle mého názoru, nemá žádný vliv na životní prostředí. Pokud ano, omlouvám se za svou neznalost."

- "Moje rozhodnutí nebude mít velký vliv na životní prostředí."

Kategorie: „Při koupi telefonu nemyslím na životní prostředí"

- „Když si chci něco koupit, nepřemýšlím, jakým způsobem to ovlivní životní prostředí. Nikdy jsem nad tím nepřemýšlela."

- „Při výběru bych nejdříve hleděl na cenu a funkce. Životní prostředí mě $\checkmark$ tomto prípadě bude také zajímat, ale nebudu podle vlivu na něj vybírat dražší typ."

- "Vůbec neřešim vztah mobilní telefon versus př́roda."

- „Myslím si, že výběr mého nového mobilního telefonu se životním prostředím vůbec nesouvisí!"

- „Přiznám se, že na životní prostředí bych v tu chvíli nemyslela."

Kategorie: „Má vliv na životní prostředí"

- "Starý mobil se stává odpadem, který se těžko likviduje. Na nový mobil je potřeba při výrobě energie, doprava..., což na životní prostředí vliv má a nikoli pozitivní."

- "Má to určitě vliv na životní prostředí (skladování odpadu jako např. akumulátorů má špatný dopad na okolní prostředí)."

- "Ovlivní ho kladně, protože už dál nebudu posílat papírové dopisy. Nebudu muset jezdit autem, abych něco zajistil. Atd."

- „Kvůli mobilním telefonům a mob. operátorům se musí stavět vysílače, které zásadním způsobem zasahují do rázu prírody a do prírody vůbec."

- „Životní prostředí ovlivňuje výroba telefonů - z jakého materiálu a znečištění prírody př̀ výrobě."

\section{Otevřená otázka č. 2:}

„Má smysl vyučovat Environmentální (Ekologickou) výchovu na školách? (napiš svůj názor ve 3-5 větách na to, proč to smysl má nebo proč to smysl nemá)" 
Obrázek 7. Smysl výuky environmentální výchovy: procentuální zastoupení jednotlivých kategorií odpovědí

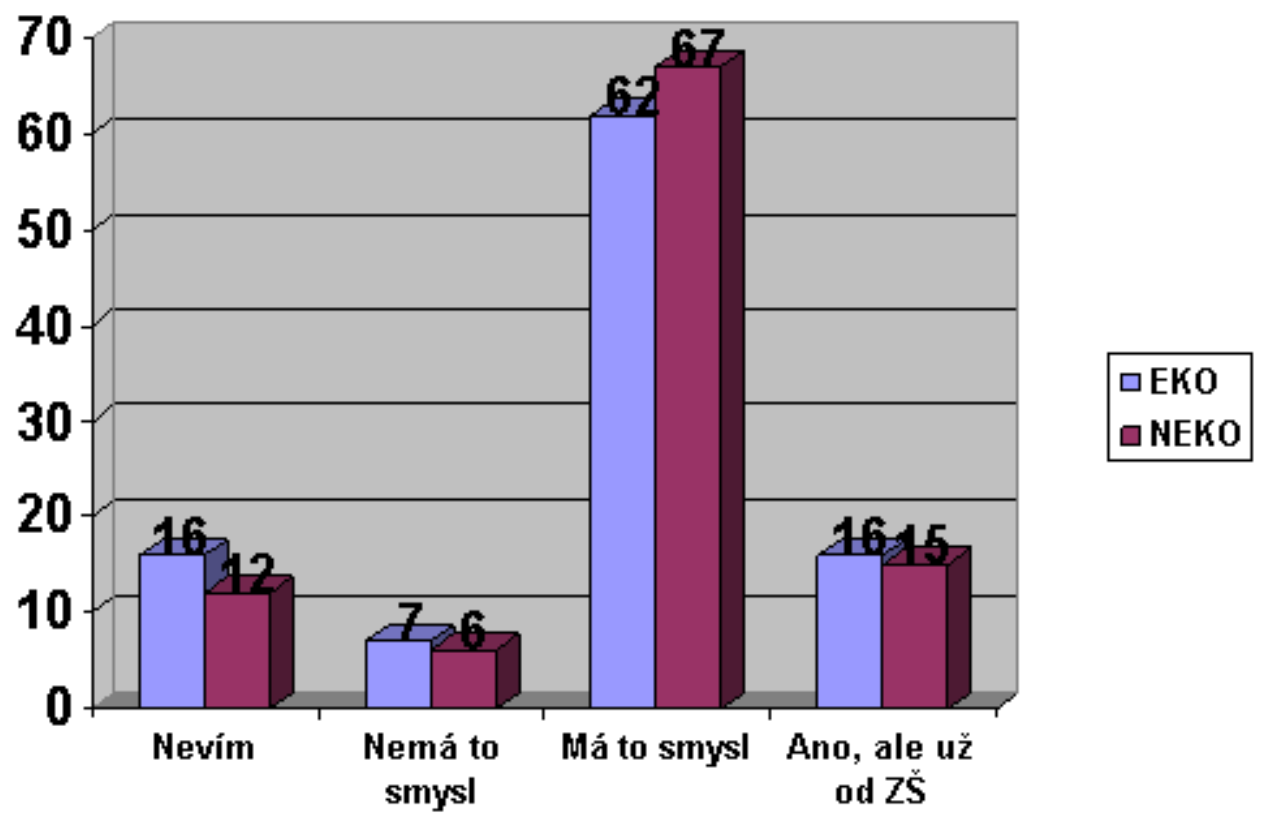

Přestože rozdíly nejsou statisticky významné je zajímavým výsledkem lehce vyšší počet respondentů z kontrolní skupiny, kteři považují environmentální výchovu za smysluplnou.

Příklady odpovědí pro každou kategorii:

\section{Studenti s proenvironmentální profilací}

Kategorie: „Nevím"

- „Pro toho, kdo se o to zajímá to smysl určitě má, ale pro toho, komu je to stejně jedno si myslím, že je to zbytečný."

- „Na jednu stranu možná, ale na druhou to nemá smysl, protože dnešní některá mládež je $v$ tomto směru úplně mimo a koho př́roda opravdu nezajímá tak je to zbytečné."

- "Myslím, že to má smysl jak pro koho. Někoho to bude bavit, někoho ne."

- "Myslim si, že to určitě je dobrý nápad. Ale zároveň bych řekla, že hodně lidí toto téma nezajímá a nebaví je to."

- „Záleží na jakých školách. Na nějakých odborných určitě, ale jinde asi ne."

Kategorie: „Nemá to smysl"

- „Tak tohle smysl určitě nemá, protože to bude akorát jeden zbytečný předmět navíc... Studenti si z něj stejně nic neodnesou a jenom proto, jak se to budou učit ve škole, nezmění své chování k přírodě..." 
- "NE"

- „Myslím si, že by se měly organizovat projekty, které lidem dají více, než pravidelná výuka $v$ hodinách. Na této škole se ekologie vyučuje, ale moc velký smysl to asi nemá."

- "Nemá to smysl, protože je již obsažena v jiných předmětech. Byla by to zbytečnost."

- "Ne, člověk je chytrej, ale lidi jsou hloupí. Nikdo si z toho moc nevezme."

Kategorie: „Má to smysl”

- "Určitě má, protože spousta lidí vůbec neví jak se má v prírodě chovat. Jedině prase dokáže udělat v lese skládku!"

- "Myslím si, že to smysl má. Každý by se měl naučit, jakým způsobem by mohl chránit přírodu. Např́klad tř́ídění odpadů..."

- "Určitě ano, protože ve školách se k tomu dostanou a zamyslí i osoby, které o tom nikdy nepřemýšlely a začnou prírodu šetřit (snad)."

- „Ano, má to určitě velký smysl a to $z$ toho důvodu, že lidé budou více vědět o ŽP a o tom, jak ho chránit. $V$ dnešní době si myslím, že je malá informovanost o tomto velkém problému."

- „Určitě, ekologická výchova je potřeba! Už jen z toho důvodu, že se objevuje stále více globálních problémů a mladí lidé by měli být informováni o tom, jak by se $\mathrm{k}$ prrírodě měli chovat, aby i jejich děti mohli poklidně žít."

Kategorie: „Ano, ale už od základní školy”

- "Nějaký význam to určitě má. Dle mého názoru by se takový předmět měl objevit u 7, 8 ročníku, dřív nebo později to nemá význam."

- „ANO - ale mělo by se s tím začít už na 1 . stupni ZŠ. Děcka alespoň vědí, jak se mají chovat v prírodě."

- "Určitě má, hlavně by se s tím mělo začít již na prvních stupních Zš, protože na středních už je pozdě. Děti se špatně převychovávají, kor v pubertě."

- "Smysl to má, chtělo by to začít vyučovat už na základních školách. Když budou děti vyrůstat, budou se pak jinak chovat."

- "Určitě to smysl má, děti by se měly už od školky učit, že mají přírodu chránit, nebo jim žádná nezbyde."

\section{Studenti s jinou profilací}

Kategorie: „Nevím”

- "Myslím, že to smysl má i nemá. Někoho to zajímá, jiného ne. A navíc ekologická opatření se rychle mění a není proto možné o všech žáky informovat."

- "Spíše jako volitelný předmět."

- „Podle mého názoru by to smysl mělo. Mohlo by to být nepovinné a třeba jen jedna hodina $v$ týdnu. Ale nevím, kolik studentů by se výuky chtělo zúčastnit." 
- "Nejsem si jistá, jestli to má smysl. Lidé vědí o problémech s životním prostředím, ale stále s tím nic nedělají a nadále ho niči."

- "Určitě je dobré dozvědět se o tom, co nejvíc a ty informace rozšiřovat dál mezi ostatní lidi. Ale jestli to má smysl, (resp. jestli to bude mít nějaký účinek), to nevim..."

Kategorie: „Nemá to smysl”

- "Myslím, že jako samostatný předmět ne, ale mohlo by být o ekologii více zmínek. I když na naší škole se tomu dost nevěnují."

- „Podle mého názoru to žádný velký význam nemá. Lepší by bylo, kdyby ekologická výchova byla zájmovým kroužkem pro ty, co o ekologii mají vážný zájem, pro ty ostatní, si myslím, že by to byla ztráta času, protože obecné informace se dozvídáme i v jiných předmětech."

- Určitě nemá."

- "Nemá smysl na to vyhrazovat speciální předmět."

- „Myslím si, že nemá. Závisí pouze na každém člověku, jak se zachová ve vztahu k prírodě."

Kategorie: „Má to smysl"

- "Má to smysl, nebot žáci si ani kolikrát neuvědomují, co se ve světě děje, jaké hrozí do budoucna problémy."

- "Určitě to smysl má. V mnoha rodinách to můžou být právě děti, které upozorní např. na tř́dění odpadu a další. Jsou to možná malé kroky, které však pomohou Zemi."

- "Má smysl, aby si člověk uvědomil, že Země je jen jedna, a proto se musí tak podle toho chovat."

- "Ano, žáci by věděli více o zlepšení životního prostředí a do budoucna by byla větší pravděpodobnost, že naše Země bude v lepšim stavu než ted'."

- „Smysl to určitě má. Myslím, že je důležité, abychom si uvědomili, čím si škodíme. A neškodíme jen zviŕratům a prostředí, ale hlavně sobě. A tomu je potřeba čelit."

Kategorie: „Ano, ale už od základní školy”

- „Podle mého názoru má smysl, abychom se starali o životní prostředí, ale měli by nás to učit už od dětství."

- "Určitě to smysl má. Děti a studenti by se měli ekologií zabývat a vědět, co se kolem nich vlastně děje."

- "Myslím, že má., protože lidé budou už od mládí seznámeni, jakým způsobem odpad tř́ídit, že naše chování ovlivňuje živ. prostředí atd."

- "Vyučování ekologické výchovy má smysl, pokud tak bude prováděno již od nízkého věku. Starší studenty už tím nezměníme."

- „Dle mého názoru ekologická výchova smysl má. Je potřeba vzdělávat již malé (školní) děti, aby věděly, jak se mají k životnímu prostředí chovat." 
Otevřená otázka č. 3:

„Co bys očekával/-a od výuky Environmentální (Ekologické) výchovy na tvé škole? (napiš svá očekávání ve 3-5 větách)"

Obrázek 8. Očekávání od environmentální výchovy: procentuální zastoupení jednotlivých kategorií odpovědí

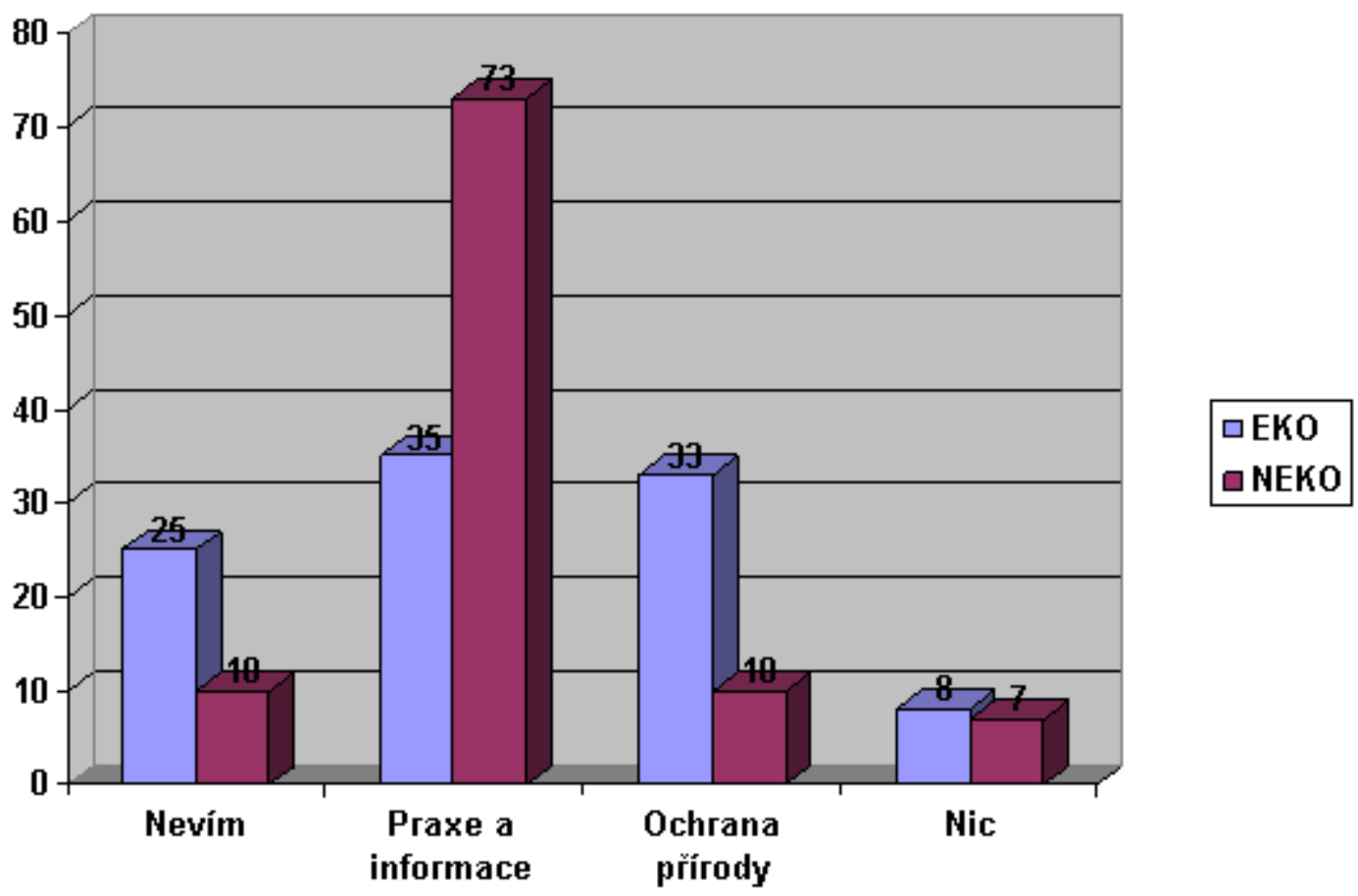

Rozdíly mezi oběma skupinami jsou v tomto případě veliké. Zarážejícím výsledkem je čtvrtina respondentů z experimentální skupiny, která svá očekávání nedokázala ani na konci studia environmentálně profilované školy vyjádřit. Respondenti z experimentální skupiny očekávají kontakt s ochranou přírody, zatímco respondenti z kontrolní skupiny praktické informace o životním prostředí.

Př́klady odpovědí pro každou kategorii:

\section{Studenti s proenvironmentální profilací}

Kategorie: „Nevím”

• "To přesně nevím, ale asi si myslím, že určitě hodně věcí."

- „Hm. Záleží na tom, kdo by to učil. Každý učitel má svůj názor a ten chtěnechtě prozradí! U některejch by slavila úspěch. Zbytek by to bral jako zbytečném předmět."

- $\quad \ldots .$.

• „Nemám tušení, co bych od výuky environmentální výchovy čekal."

- "Tak to nevím, protože nevím, jak by měla výuka vypadat, nedokážu si to predstavit." 
Kategorie: „Praxe a informace"

- "Očekával bych informace, jak co dělat šetrněji k př́rodě. Také informace o nových trendech."

- „Nezkreslené informace, přesné příklady (kde je jaký problém) jak můžeme zlepšit situaci z našeho postavení."

- „Úplné základy, myslím si, že důležitá je i praxe. Na jednom kurzu jsme sbalili pytle a šli sbírat odpadky po jedné vesnici. Od té doby bych už nic nevyhodila jen tak do prírody."

- "Co bych očekávala? Očekávala bych, aby nás brali na různé výlety (exkurze), při kterých bychom poznávali přírodu a dělali věci, které přírodě neškodí. Více s námi diskutovali o problémech."

- "Očekávala bych i třeba nějakou praktickou zkušenost. Třeba jít si někdy na celý den sbírat někam odpadky. Aby lidi konečně pochopili jak je naše príroda znečištěná."

Kategorie: "Ochrana prírody"

- „Jak bych se měla chovat ke svému okolí ještě lépe, nebo podporovat různé programy a zapojovat se do nich. Pečovat o př́rodu."

- „Aby ukázala, do jaké míry náš běžný život poškozuje okolí. Předvést, jak své chování zlepšit a zapojit nás do ochrany."

- "Mělo by se $v$ těchto hodinách vyučovat o tom, jakým způsobem lidé škodí životnímu prostředí a jak by se tomu mělo předcházet, co je škodlivé a co ne a jakým způsobem nakládat s některými druhy odpadů."

- "Tak jak se chovat v prírodě nebo okolo svého bydliště."

- „Asi bych chtěla vědět, co je dobré a co špatné pro živ. prostředí, i když se o tom docela dost mluví. A asi bych očekávala, že nám vyučující řekne, jak se máme chovat, abysme zabránili ničení živ. prostředí..."

Kategorie: „Nic"

- "Nic nového pod sluncem. Kdo má zájem o ekologii tak si informace může najít. Zbytečné zatěžování žáků/studentů."

- "Očekával jsem to, co jsem se naučila."

- "Jelikož školu již dokončuji, tak již nemohu v tomto směru nic očekávat."

- „Nic! Základy o ekologii mám ze ZŠ a víc mě nějak nezajímá. Vím jak se chovat v prírodě i jak se o ni starat."

- " „Snaha tu je, ale nic zvláštního od toho nečekám."

\section{Studenti s jinou profilací}

Kategorie: "Nevím"

- ${ }_{1 . . . . "}$

- "Nechodil bych tam!" 
- "Netuším a je to stejně jedno, protože zákony jsou důležitější než výchova."

- „Nevím čeho se to týká."

- "Nevím, ty studuješ VŠ :)"

Kategorie: „Praxe a informace"

- "Nějaké zajímavé informace o vztahu k přírodě, něco co by přesvědčilo většinu."

- "Základní zásady: třídění odpadu atd. Spíše praktická výuka hrou než teorie."

- „Informace o současném stavu životního prostředí a rady, jak se chovat a jak mohu prostředí sama ovlivnit a pomoci mu."

- „Že i škola sama se bude ekologicky chovat! - více třídit odpad, nepoužívat zbytečně mnoho materiálů při výuce (papíry,...). Praktické začlenění výuky do okolí školy (sběr odpadkư, sázení rostlin,...)."

- „Efektivní, názorná výuka. Ne pouze předkládat holá fakta @ diskuze, úvahy, exkurze atd."

Kategorie: "Ochrana prírody"

- „Jak se chovat k prostředí, aby zůstalo hodně i pro budoucnost. Obecně seznámení s ekologií (co, proč, jak...)."

- "Očekávala bych, že nás naučí, jak se chovat šetrně k prírodě, abychom ji zachovali krásnou příštím generacím."

- „Základní informace o životním prostředí, jak ho Ize chránit, co můžeme pro něj udělat my sami, co životní prostředí škodí, informace o alternativní energii."

- "Že mi charakterizuje prírodu a řekne, co by se dělat mělo a co ne."

- „Měla by mě naučit lepšímu chování $k$ prírodě a prohloubit naše znalosti v tomto směru."

Kategorie: „Nic"

- "Nic."

- "Nic moc, protože učitelé mají malé platy a proto by to tak neprožívali."

- „Já myslím, že o tomto již dost vím ze základní školy a z novin a dalších publikací."

- "Vůbec nic."

- "Nevím. Neočekávám od toho nic."

\section{Diskuze a závěry}

Hypotéza H1: "Žáci škol, které se profilují na environmentální výchovu, vykazuji $\checkmark$ posledních ročnících častěji proenvironmentální postoje, jednání a porozumění environmentálním tématům než žáci posledních ročníků jinak profilovaných škol." 
Tuto hypotézu se nepodařilo potvrdit. Rozdíly mezi experimentální a kontrolní skupinou byly ve většině případů nevýznamné a jediné výjimky byly ve prospěch kontrolní skupiny. Ta vykazovala větší míru identifikace s principy udržitelného rozvoje a globální odpovědnosti a současně byla ochotnější rozšiřovat informace od ekologických organizací.

H2:Žáci škol, které se profilují na environmentální výchovu, se více angažují při poukazování nebo řešení environmentálních problémů v jejich okolí poprípadě ve světě než žáci jinak profilovaných škol.

Ani tuto hypotézu se nepodařilo potvrdit. Respondenti z experimentální skupiny sice častěji doma třídí odpad, studenti z kontrolní skupiny ale častěji přispívají na charitu. Rozdíly v dalších činnostech byly nevýznamné.

Výsledky průzkumu nelze vzhledem k malým velikostem skupin př́liš zobecňovat. Pokud ale budeme považovat použitou metodiku za relevantní, je zjevné, že studenti ze zkoumaných environmentálně profilovaných středních škol odchází zhruba se stejnými postoji $\mathrm{k}$ životnímu prostředí a stejnými vzorci jednání, jako jejich vrstevníci z environmentálně nezaměřených škol.

Je zřejmé, že přesnější výsledky o vlastním přínosu environmentálních kurikulí experimentálních škol by přinesl pouze dlouhodobý výzkum, který by měřil posun jednotlivých studentů od prvního ročníku do posledního. Na druhé straně je možné předpokládat, že profilace škol ovlivňuje zájem uchazečů a že se tedy na školy hlásí studenti s teoreticky vyšší hladinou proenvironmentálních postojů než na jinak se profilující školy. Takový předpoklad by ale musel být dále ověřován šetřením mezi studenty prvních ročníků.

Přínos environmentálně profilovaných škol na formování postojů a jednání svých studentů v oblasti životního prostředí se nepodařilo prokázat.

\section{Literatura}

- Čninčera, J. . P.T. : Statistika závěrečného hodnocení. 2007. Interní dokument, nepubl.. .

- Činčera, J., \& Štěpánek, P. (2007). Výzkum ekologické gramotnosti studentů středních odborných škol. Envigogika, 2(1), 2007-12. Retrieved from http://www.envigogika.cuni.cz/index.php/Envigogika/article/view/12 http://dx.doi.org/10.14712/18023061.12

- Glierová, B. (2007). EKOGymnázium Poděbrady : Klub ekologické výchovy. . Retrieved from http://www.ekopodebrady.cz/ekogymnazium/projekty-eu/klub-ekologicke-vychovy-kev/

- Gymnázium Jiř́ho z Poděbrad : Školní vzdělávací program (2007). . Retrieved from http://www.gjp.cz/verej dokumenty/SVP NG GJP.pdf

- Gymnázium T. G. Masaryka : Projekty (2007). . Retrieved from http://www.gymhust.cz/projekty.htm

- $\quad$ SZeŠ a SOŠ, Prírodovědné lyceum : Charakteristika studijního oboru (2006). . Retrieved from http://info1.nuov.cz/nuov-docs/ZPDTEXTY/78/7842M006.ch.html

\section{Př́loha}

Př́loha - Hodnoty T-testu pro jednotlivé otázky a číselné výsledky po jednotlivých školách a text dotazníku (ve formátu pdf) 


\section{Recenzní posudky}

Recenzent nesouhlasí se zveřejněním jména.

„Článek kvalitním způsobem prezentuje výzkum věnující se aktuálnímu problému evaluace environmentálního vzdělávání. Je jasně a logicky uspořádán, nechybí žádná podstatná informace. Základní cíl výzkumu (komparace postojů a jednání studentů environmentálně orientovaných středních škol se studenty z jinak zaměřených škol) je príslibem zajímavých výsledků, které by mohly pedagogům poskytnout potřebnou zpětnou vazbu.

$\checkmark$ př́padě hlubšího zájmu o výzkumný nástroj autor odkazuje na článek J. Činčery a P. Štěpánka z prvního letošního čísla Envigogiky, kde je vývoji dotazníku věnován potřebný prostor. Jedná se o velmi důležitý odkaz, protože prípadné výhrady, které by čtenáŕ mohl $k$ prezentovanému textu mít, by zřejmě směřovaly $k$ validitě výzkumného šetření.

Zjišt́uje např. výrok: „Zvířata a rostliny maji stejná práva existovat jako lidé" skutečně míru proenvironmentálního postoje, když souhlasná odpověd' je přinejmenším diskutabilní nebo spiše chybná? Snad by bylo možné otázku postavit hypoteticky (měli by mít...).

Podobně u výroku: „Mám rád/-a místo, ve kterém žiji” jistě naměříme vztah $\mathrm{k}$ respondentovu prostředí, ale o povaze tohoto prostředí už nevíme nic. Jinými slovy: pokud bude napríklad respondent žít $v$ části města přetižené automobilovou dopravou, může k tomuto "místu" chovat poměrně negativní vztah, ale o to více bude zastávat názory blízké udržitelnému rozvoji.

Bylo by možné diskutovat např. o otázkách 5,13 a snad i 14, kde může být důraz na slovo "morální" různě pochopen, a snad by byla vhodnější formulace bližší definici udržitelného rozvoje ve zprávě G. H. Brundtlandové (uspokojování potřeb současných generací, aniž by byly ohroženy potřeby generací prríštích).

Také pojmenování dominantní společenské a nové environmentální paradigma můžeme chápat spíše jako termíny odkazující na historii vzniku této metody měření postojů, protože dnes již zřejmě budou, alespoň v odpovědích při sociologickém tázání, dominovat postoje blízké NEP (jak se dozvídáme i ve zmíněném článku z Envigogiky 1/2007).

Je potřeba zdůraznit zodpovědný kritický přístup, jakým se autor staví k výsledkům. Nepouští se do nepodložených spekulací, drží se ryze deskriptivní interpretace a nesnaží se závěry zkoumání nadneseně zobecňovat. Přesto by ale některá zjištění, jako např. větší míra proenvironmentálních postojů u studentů kontrolní skupiny, stála za hlubší zamyšlení než jen strohé konstatování, že se jedná o „zarážejíci" výsledek.

Je třeba vyzdvihnout práci, která byla $v$ rámci výzkumu odvedena, at́ už se jedná o celkově zodpovědně navržené a realizované šetření či o konkrétní ochotu $k$ docílení co nejlepších výsledků zařazením volných otázek a jejich následnou kategorizaci. Měření postojů představuje nesnadnou a problematickou kapitolu vědeckého zkoumání. Je proto nutné ocenit výzkum, který rozvíjí a testuje velmi potřebnou metodiku hodnocení environmentálního vzdělávání." 
Časopis Envigogika vydává Centrum pro otázky životního prostředí UK. Vývoj časopisu je podpořen projektem OP VK Mezioborová sít udržitelného rozvoje.

Více najdete na internetových stránkách projektu mosur.czp.cuni.cz
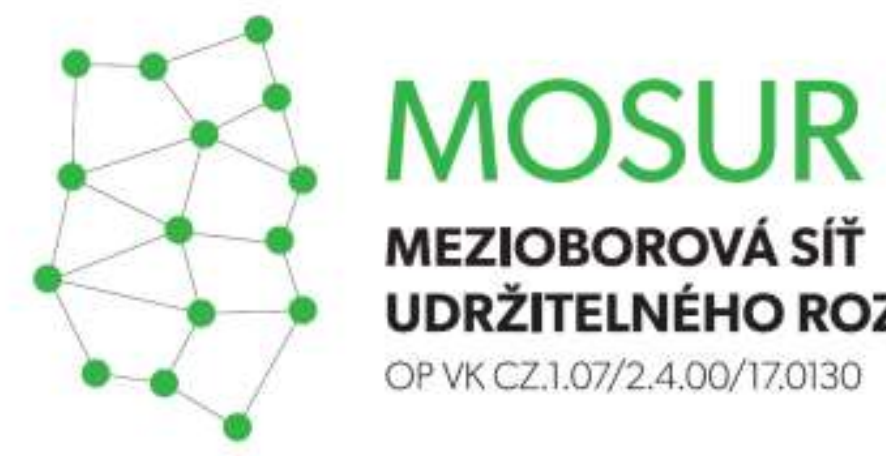

\section{MEZIOBOROVÁ SÍT} UDRŽITELNÉHO ROZVOJE

OP VK CZ.1.07/2.4.00/17.0130
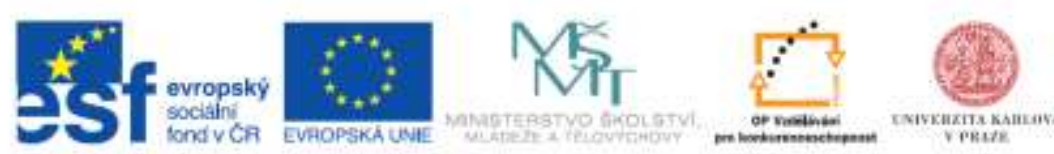

INVESTICE DO ROZVOUE VZDELAVANI 